Research Article

\title{
Biosynthesis of Silver Nanoparticles Using Two Seaweeds and Their Potential Towards Environment
}

\author{
Dhanalakshmi Aravindan, Riyazulla Azeez, Thangaraju Nallamuthu \\ Centre for Advanced Studies in Botany, University of Madras, Guindy Campus, Guindy, Chennai 600025 \\ Corresponding author: E-mail: dhanambio@gmail.com
}

Received: Sept. 22, 20I4; Accepted: Dec. 15, 20I4; Published: Dec. 25, 2014.

Citation: Dhanalakshmi Aravindan, Riyazulla Azeez and Thangaraju Nallamuthu. Biosynthesis of Silver Nanoparticles Using Two Seaweeds and Their Potential Towards Environment. Nano Biomed. Eng. 2014, 6(4), 94-103.

DOI: 10.5101/nbe.v6i4.p94-103.

\begin{abstract}
Nano-biotechnology is recognized as offering revolutionary changes in various fields of medicine. Biologically synthesized silver nanoparticles have a wide range of applications. The biosynthesis of silver nanoparticles is an eco-friendly method in the field of nanotechnology. Seaweed extracts of Caulerpa racemosa (Forsskål) J. Agardh and Ulva lactuca Linnaeus was used as a reducing agent in the eco-friendly extracellular synthesis of silver nanoparticles from an aqueous solution of silver nitrate $\left(\mathrm{AgNO}_{3}\right)$. High conversion of silver ions to silver nanoparticles was achieved with Ulva lactuca at reaction temperature of $100{ }^{\circ} \mathrm{C}$ and a seaweed extract concentration of $10 \%$ with a residential time of $1 \mathrm{~h}$ using reflux extractor when compared with the other methods. Formation of silver nanoparticles was characterized by spectrophotometry and the electron microscopic technique. The average particles size was ranging from 35 to $75 \mathrm{~nm}$. Antimicrobial activities indicate the minimum inhibitory concentration of biologically synthesized nanoparticles tested against the pathogen Staphylococcus aureus $(1 \mathrm{mg} / \mathrm{ml})$. High inhibitions over the growth of Pseudomonas aeruginosa, Vibrio cholerae and Escherichia coli were witnessed against the concentrations of $1 \mathrm{mg} / \mathrm{ml}$. Enzyme assay of the collected seaweeds performed using standard protocol to assess the potency level. Further, seed germination test proved that synthesized nanoparticles were environmentally safe, for which the same can be used for effluent treatment process.
\end{abstract}

Keywords: Bionanoparticles; Antimicrobial activity; Photocatalytic degradation; Seed germination

\section{Introduction}

Terrestrial resources being greatly explored and exploited, researchers turn to the oceans for numerous reasons. In recent years, many bioactive compounds have been extracted from various marine plants, marine animals and marine organisms. Seaweeds are marine plants because they use the sun's energy to produce carbohydrates from carbon dioxide and water. In India seaweeds are mainly exploited by industries for phycocolloids but very poorly explored for their beneficial application in pharmacology. Seaweeds are important sources of protein, iodine, vitamins, minerals and polyphenols with their metabolites showing wide range of promising biological activities. Over the past several decades, seaweeds and their extracts have generated an enormous amount of interest in the pharmaceutical industry as a fresh source of bioactive compounds with immense medicinal potential. The synthesis of inorganic nanomaterial's has been 
demonstrated by several methods including physical, chemical and biological [25, 14 \& 20]. However, chemical methods for synthesis of metal nanoparticles have been more popular and have gained wide acceptance [9, $21 \& 32]$ towards synthesis of metal nanostructures due to easy protocols and the fine shape and size control provided.

Currently, the green synthesis of metallic nanoparticles is being investigated to improve and/ or protect the environment by decreasing the use of toxic chemicals and eliminating biological risks in pharmaceutical and biomedical applications. For the development of green chemistry, Raveendran $P$ suggested that three main factors in nanoparticle preparation should be considered: solvent choice, the use of an environmentally benign reducing agent, and the use of a non-toxic material for nanoparticle stabilization [27]. Recently, biological entities have been reported as serving as both reducing and stabilizing agents for green synthesis of metallic nanoparticles [35]. However, in minute concentrations, silver is nontoxic to human cells. Keeping the biological perspectives in mind, the results reported herein encompass the biological synthesis of silver nanoparticles and their antimicrobial activity.

Till date, several plant systems have been used for the synthesis of nanomaterials of different shapes, sizes and compositions [1-2, 11-12 \& 3031]. Recently, there is a study on the extracellular biosynthesis of monodisperse gold nanoparticles using the marine alga, Sargassum wightii [33]. In the present study, we have synthesized silver nanoparticles by the reduction of aqueous $\mathrm{AgNO}_{3}^{-}$by the extract of marine algae Caulerpa racemosa (Forsskål) J. Agardh and Ulva lactuca Linnaeus. Further, Catalytic reduction, Photocatalytic degradation and Seed germination test of the extract and synthesized particles were processed.

\section{Experimental section}

\section{Methods}

\section{Preliminary biochemical analyses}

Analyses were carried out in triplicates using fresh frozen samples to overcome any error. Biochemical estimations like, Chlorophyll [23], Phycoerythrin, Phycocyanin and Allophycocyanin [4], Total Protein [5], Total Lipid [10], Total Carbohydrate [8] was carried out by standard procedures.
Seaweed extracts preparation and phytochemical estimation

$5 \mathrm{~g}$ seaweed samples were dissolved in sterile water, methanol, ethyl acetate, hexane and kept under repeated freeze thawing followed by sonication (1 min on, $10 \mathrm{sec}$ off condition) for three days as per standard protocol. After incubation the samples were dried under room temperature, weighed and stored at $-4^{\circ} \mathrm{C}$ until use. Phytochemical estimation was performed in triplicates to avoid error as follows, Alkaloids, Carbohydrates, Saponin, Protein and Amino acids, Phytosterols, Phenolic compounds, Flavonoids, Steroids, Terpenoids and Cardiac glycosides [13].

\section{Enzyme assays}

Enzyme assay was performed by preparing the extract from fresh seaweeds using extraction buffer maintained at $4^{\circ} \mathrm{C} .0 .5 \mathrm{~g}$ fresh seaweed was grinded with sodium phosphate buffer/extraction buffer according to the assay and centrifuged to collect the supernatant. This solution was used for further determination of assay. Determination of Catalase activity (CAT, EC 1.11.1.6) [3], ascorbate peroxidase activity (APX, EC 1. 11. 1. 11) [7], Peroxidase (POX, EC 1.11.1.7) [6], Polyphenol oxidase activity assay (PPO, EC 1. 14. 18. 1) [18] were some of the assays carried out.

\section{Antioxidant activity of seaweed extracts}

Some of the antioxidant assays were performed by following standard protocols such as, total phenol [34], total condensed tannin [16], thiobarbituric acid (TBA) test [17], Hydrogen peroxide radical scavenging activity, total reducing power assay and total antioxidant capacity [26].

\section{Nanoparticle synthesis}

Silver nitrate stock solution $\left(10^{-3}\right.$ concentration) was prepared using deionized water. Various methods like, boiling $\mathrm{AgNO}_{3}$ solution with sample extract, by boiling sample extract alone and using reflux extractor were followed.

\section{By boiling sample extract}

$5 \mathrm{~g}$ of seaweeds were weighed and dissolved in sterile deionized water and boiled for $1 \mathrm{hr}$. After cooling, extract was filtered and $5 \mathrm{ml}$ of the same was added to $95 \mathrm{ml}$ of $\mathrm{AgNO}_{3}$ stock solution and kept for incubation under dark until colour change occurs.

\section{By boiling extract with $\mathrm{AgNO}_{3}$ solution}


$5 \mathrm{~g}$ of seaweeds were weighed, dissolved in sterile deionized water and incubated for $48 \mathrm{hrs}$ at room temperature. After incubation extract was filtered and $5 \mathrm{ml}$ of the extract was added to $95 \mathrm{ml}$ of $\mathrm{AgNO}_{3}$ stock solution. This mixture was kept in boiling water bath for 30 mins.

\section{By using reflux extractor}

$5 \mathrm{~g}$ of seaweeds were weighed, dissolved in sterile deionized water and kept for refluxing at $70^{\circ} \mathrm{C}$ for 1 hr. $95 \mathrm{ml}$ of $\mathrm{AgNO}_{3}$ stock solution was added to $5 \mathrm{ml}$ of the prepared extract and incubated under dark until colour change.

\section{Characterization of synthesized nanoparticles}

\section{UV-Visible Spectroscopy}

UV-Vis spectrophotometer experiment was carried out on a Shimadzu UV-8500 PC scanning spectrometer using $\mathrm{AgNO}_{3}$ as the reference. 2-3 drops of the sample was pipetted into quartz UV Cell $(2 \mathrm{ml})$ and diluted with deionized water, followed by immediate spectral measurements. Deionized water was used as blank for all measurements.

\section{Fourier Transform Infrared Spectroscopy}

FT-IR (Spectrum RX-1 instrument) was used for the analysis of the water extract of sample and sample synthesized nanoparticles. The spectrum was focused in the range $400-4000 \mathrm{~cm}^{-1}$ by the $\mathrm{KBr}$ pellet technique.

\section{Scanning Electron Microscope (SEM)}

SEM analysis was done using Hitachi S-4500 SEM machine. Thin films of the sample were prepared on a carbon coated copper grid by just dropping a very small amount of the sample on the grid, extra solution was removed using a blotting paper and then the film on the SEM grid were allowed to dry by putting it under a mercury lamp for $5 \mathrm{~min}$.

\section{$X$-Ray Diffraction (XRD) analysis}

Crystallographic information of the bioreduced Silver Nitrate solution was dried. XRD patterns were recorded by a SEIFERT X-ray diffractometer with $\mathrm{cu} \mathrm{K} \alpha$ radiation. The samples were scanned in the $2 \theta$ range of $10^{\circ}-70^{\circ}$.

\section{Transmission Electron Microscopy (TEM)}

Examination of the nanoparticle morphology by transmission electron microscopy was performed on a CM12 Philips model in SAIF, IIT Madras with an electron kinetic energy of $120 \mathrm{KV}$. For sample preparation a drop of silver solution was dispensed onto a carbon coated copper grid.

\section{Antibacterial activity of the extracts and nanoparticles synthesized}

Escherichia coli, Staphylococcus aureus, Vibrio cholerae, Pseudomonas aeruginosa were maintained in Muller Hinton broth for determining the activity of the reflux extract and synthesized nanoparticles. The agar well diffusion method was employed to determine the antimicrobial activities of the respected extracts. Well diffusion assay was found to be a simple, cheap and reproducible practical method [29]. A suspension of each sample tested micro-organism diluted prior to $10^{-1}, 10^{-2}$ and $10^{-3}-\left(1 \mathrm{ml}\right.$ of $10^{8}$ cells $\left./ \mathrm{ml}\right)$ was spread on a solid agar medium in Petri dishes (Mueller-Hinton agar). Finally the well were pierced using cork-borer and samples along with positive and negative controls were loaded onto the wells after labeling the plates, then incubated at $37^{\circ} \mathrm{C}$ for $24 \mathrm{~h}$. The diameters of the inhibition zones were measured in millimeter.

\section{Seed germination test (Raquel Barrena et al., 2009)}

The phytotoxicity of NPs was evaluated by the seed germination technique. The germination index has been extensively used as an indicator of phytotoxicity in soils [36-37]. Cucumber (Cucumis sativus) seeds were used for this test. The seed germination percentage and root length of cucumber seeds were determined after 7 days of incubation at $25^{\circ} \mathrm{C}$. The seed germination percentage and root elongation of both seeds in distilled water were also measured and used as a control. Experiments were done in triplicate. The percentages of relative root elongation (E) and germination index (GI) were calculated according to standard methods [36].

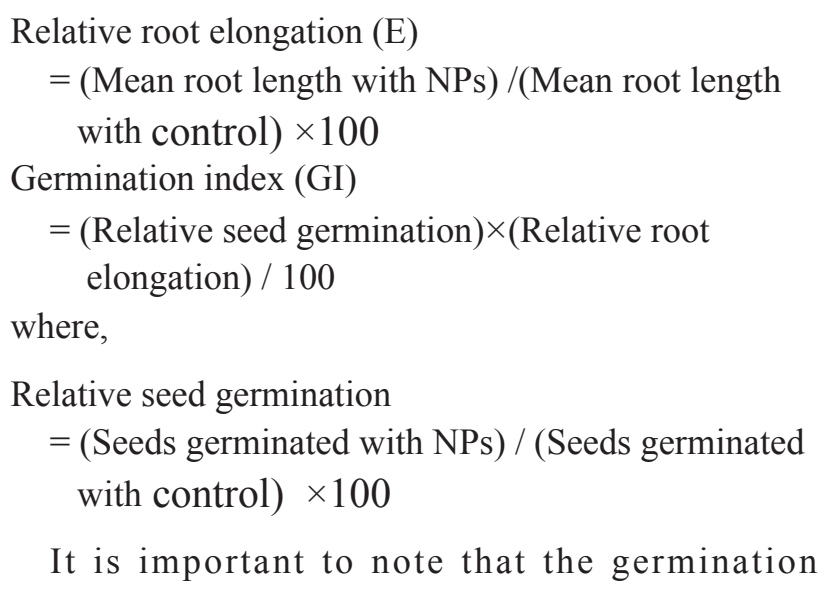


index combines germination and root growth and consequently and therefore reflects the toxicity more completely. The root elongation is the percentage of root length compared to control and it can be an indication of the presence of stress effects or other non-acute toxicological effects in the plant evolution. Hence, the root elongation can be more sensitive than the germination index when the toxicity directly affects the root development.

\section{Results and Discussion}

The main objective of the work was to evaluate and compare the ability of macro algal species from southwest coast of India to synthesis nanoparticles which are environmentally safe. The study also focuses on the antimicrobial potential of the extracts and synthesized sample for biomedical applications.

\section{Preliminary biochemical analyses}

From the estimations carried out (Fig. 1), percentage of chlorophyll was showed maximum of $17 \%$ in Ulva lactuca whereas $7 \%$ in Caulerpa racemosa. From the data, Ulva lactuca showed maximum pigment concentration.

\section{Phytochemical screening}

The ethyl acetate, methanol and hexane extracts of seaweed samples were obtained for phytochemical analyses (Table 1). Triplicates were performed for this assay. From the results, all the phytochemicals (Alkaloids, Carbohydrates, Saponin, Protein and Amino acids, Phytosterols, Flavonoids, Steroids, Terpenoids and Cardiac glycosides) were present in

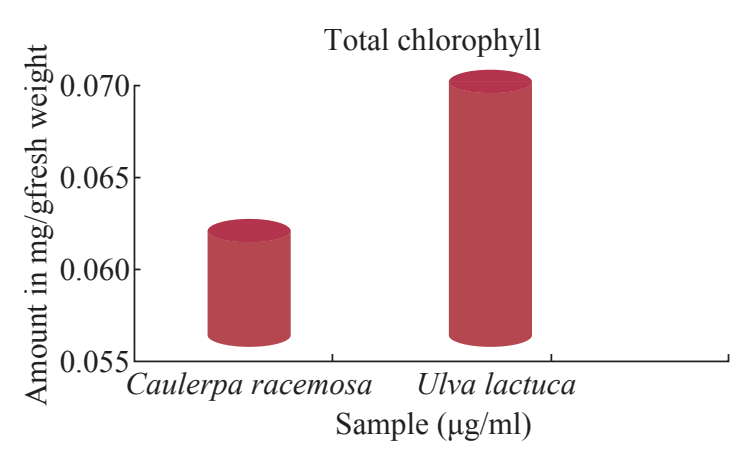

Fig. 1 Estimation of total chlorophyll.

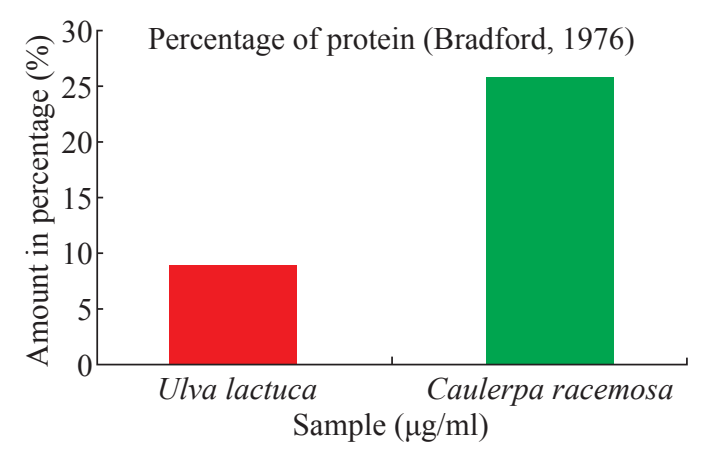

Fig. 2 Estimation of protein for seaweeds sample.

ethyl acetate extracts of Caulerpa racemosa whereas, phytochemical polyphenol were absent on ethyl acetate and hexane extract of Ulva lactuca and methanolic extract of Caulerpa racemosa.

\section{Enzyme assays}

Enzyme assays was not carried out as frequently from the analyzed data's, thus this study focuses on some of the enzyme activity of fresh seaweeds. From the enzyme assay data evaluated, Ulva lactuca shows maximum $187 \%$ of catalase activity and $160 \%$ in Caulerpa racemosa. Activity of ascorbate peroxidase

Table 1 Phytochemical screening of seaweed extracts

Solvents Seaweeds Alkaloids Terpenoids Steroids Coumarin Saponin Flavonoids Anthroquinine Polyphenols Glycosides Protein Carbohydrate

\begin{tabular}{|c|c|c|c|c|c|c|c|c|c|c|c|c|}
\hline \multirow{2}{*}{$\begin{array}{c}\text { Ethyl } \\
\text { acetate }\end{array}$} & $\begin{array}{c}\text { Ulva } \\
\text { lactuca }\end{array}$ & + & + & + & + & + & + & + & - & + & + & + \\
\hline & $\begin{array}{l}\text { Caulerpa } \\
\text { racemosa }\end{array}$ & + & + & + & + & + & + & + & + & + & + & + \\
\hline \multirow{2}{*}{ Hexane } & $\begin{array}{c}\text { Ulva } \\
\text { lactuca }\end{array}$ & + & + & + & + & + & + & + & - & + & + & + \\
\hline & $\begin{array}{l}\text { Caulerpa } \\
\text { racemosa }\end{array}$ & + & + & + & + & + & + & + & + & + & + & + \\
\hline \multirow{2}{*}{ Methanol } & $\begin{array}{c}\text { Ulva } \\
\text { lactuca }\end{array}$ & + & + & + & + & + & + & + & + & + & + & + \\
\hline & $\begin{array}{l}\text { Caulerpa } \\
\text { racemosa }\end{array}$ & + & + & + & + & + & + & + & - & + & + & + \\
\hline
\end{tabular}

Note: + - Present, - - Absent 
was $152 \%$ in Ulva lactuca whereas $128 \%$ only in Caulerpa racemosa. Maximum of peroxidase activity was showed $145 \%$ in Ulva lactuca and $128 \%$ in Caulerpa racemosa. Maximum polyphenol oxidase activity was $170 \%$ in Ulva lactuca and minimum of $128 \%$ in Caulerpa racemosa (Table 2).

\section{In vitro antioxidant activity}

Maximum total phenol was showed in ethyl acetate extract of Caulerpa racemosa $(0.98 \mathrm{mg} \mathrm{CE} / \mathrm{g})$ and minimum in hexane extract of Caulerpa racemosa (0.32 mg CE/g) (Fig. 4). Total condensed tannin (Fig. 4) was showed maximum in methanolic extract of (29.01 $\mathrm{mg} / \mathrm{g}$ ) Ulva lactuca and minimum in ethyl acetate extract of $(23.7 \mathrm{mg} / \mathrm{g})$ Caulerpa racemosa. The total antioxidant activity (Fig. 5) was maximum in ethyl acetate and methanolic extract of Ulva lactuca whereas hexane extract was minimum in both the samples. Considering, total reducing power assay Ulva lactuca showed better reducing power than Caulerpa racemosa (Fig. 6). Many species of seaweed possess scavenging ability of hydrogen peroxide. The maximum scavenging activity was shown by the methanol extract of Ulva lactuca (78.14 $\pm 0.31 \%$ inhibition) (Fig. 7) and minimum in Caulerpa racemosa (70.08 \pm 0.09$)$. The antioxidant activity of $\alpha$-tocopherol was high in ethyl acetate extracts of Ulva lactuca followed by hexane and methanolic extracts. Least activity was shown in hexane extract of Caulerpa racemosa.

\section{Nanoparticle synthesis and characterization}

Among the three methods verified, extract obtained from reflux extractor shows more synthesizing capacity. Color change from pale brown to deep red

Table 2 Enzyme assays of seaweeds

\begin{tabular}{ccccc}
\hline Sample & Amount in $\mu \mathrm{m} / \mathrm{g}$ & APX activity (nmol/min) at $290 \mathrm{~nm}$ & Amount of POD in U/mg & PPO (A575 min/g Fresh weight) \\
\hline Control & $0.15 \pm 0.05(100)$ & $7.26 \pm 0.01(100)$ & $2.26 \pm 0.01(100)$ & $3.93 \pm 0.03(145)$ \\
Ulva lactuca & $0.48 \pm 0.06(187)$ & $11.03 \pm 0.03(152)$ & $3.7 \pm 0.04(128)$ & 0.245 \\
Caulerpa racemosa & $0.32 \pm 0.03(160)$ & $10.87 \pm 0.04(128)$ & 0.178 \\
\hline
\end{tabular}
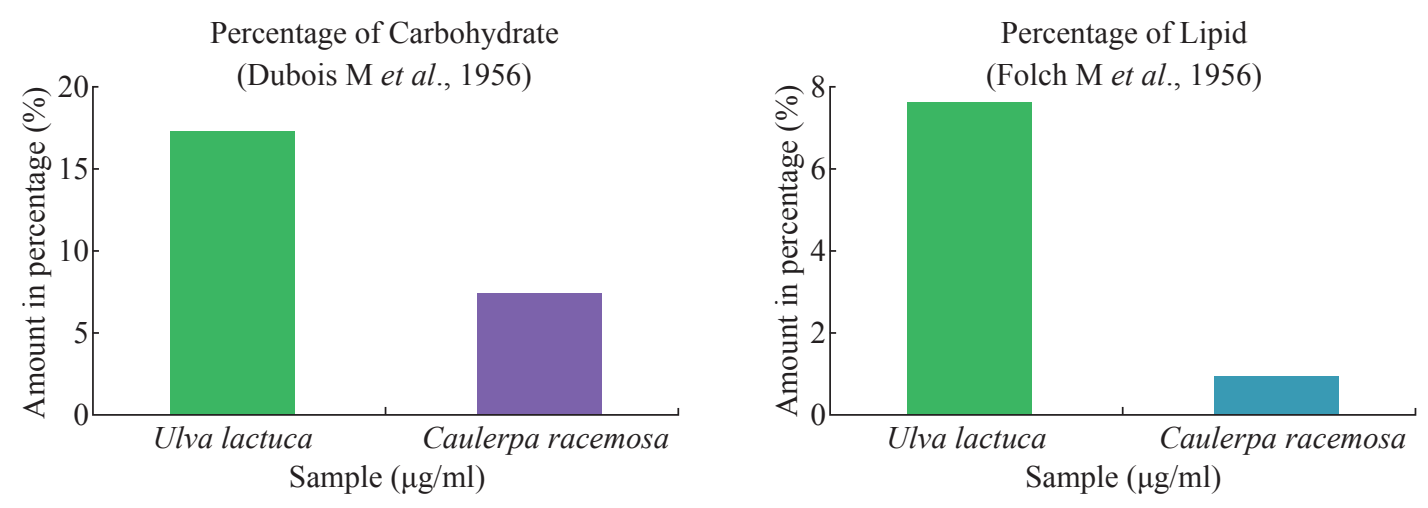

Fig. 3 Estimation of carbohydrate and lipid for seaweeds sample.
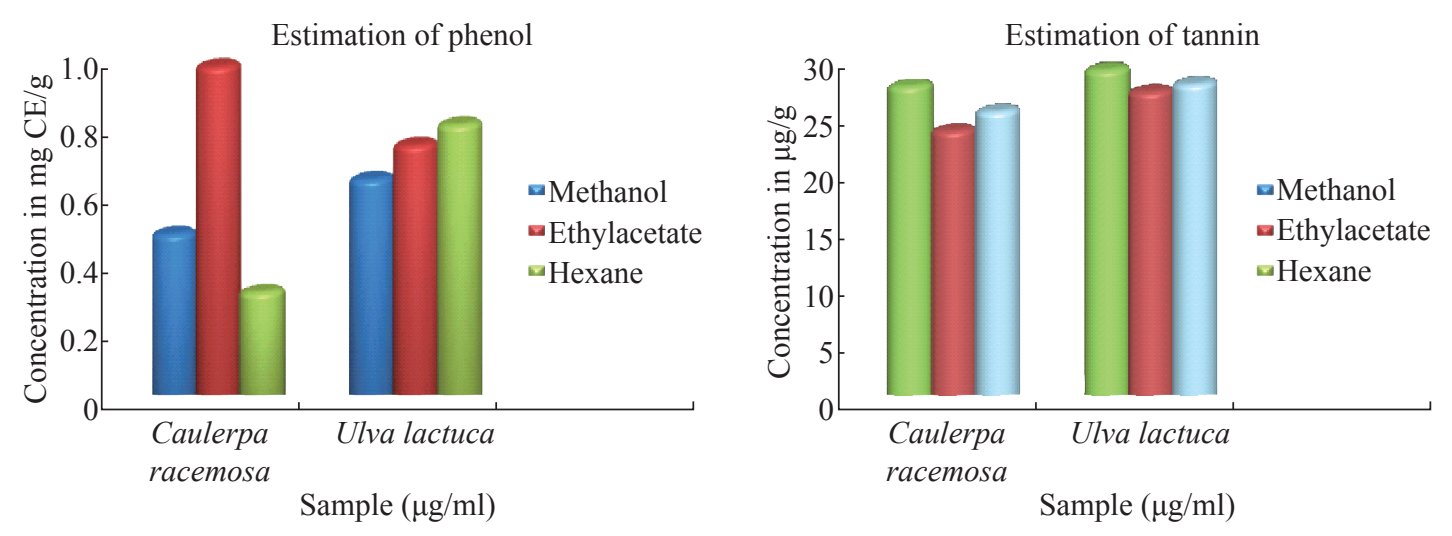

Fig. 4 Estimation of total phenol and condensed tannin. 


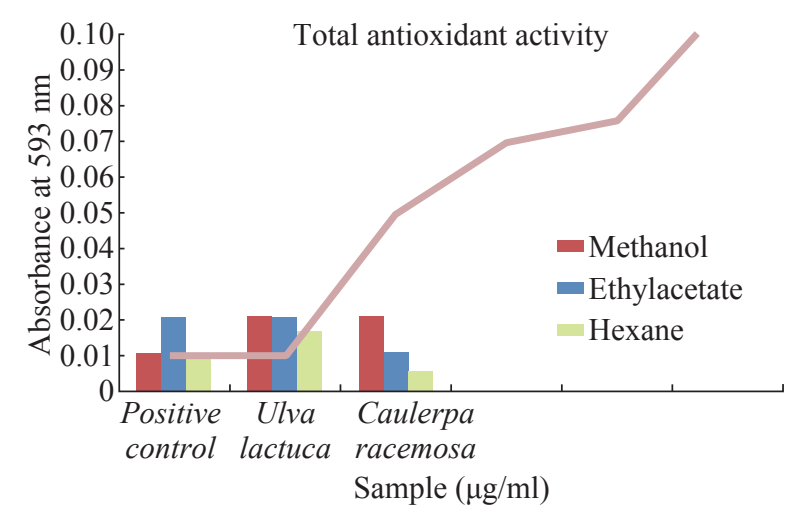

Fig. 5 Estimation of total antioxidant activity.

indicates the formation of silver nanoparticles.

\section{Characterization of synthesized particles}

UV-Spectroscopic data revealed the absorbance peak at $430 \mathrm{~nm}$ for Ulva lactuca and $420 \mathrm{~nm}$ for Caulerpa racemosa. Stability was maintained for Ulva lactuca synthesizing nanoparticles (Fig. 8).

FT-IR spectroscopic data predicts the molecular configuration of different functional group present in the seaweed extract. Considerable absorption peak were found at $3475.33 \mathrm{~cm}^{-1}, 2071 \mathrm{~cm}^{-1}, 2073 \mathrm{~cm}^{-1}, 1638$ $\mathrm{cm}^{-1}, 698 \mathrm{~cm}^{-1}, 1069 \mathrm{~cm}^{-1}, 1637 \mathrm{~cm}^{-1}, 689 \mathrm{~cm}^{-1}, 3432$ $\mathrm{cm}^{-1}, 1121 \mathrm{~cm}^{-1}, 1637 \mathrm{~cm}^{-1}, 2676 \mathrm{~cm}^{-1}, 2777 \mathrm{~cm}^{-1}$ and $686 \mathrm{~cm}^{-1}$ respectively. The peak corresponding to 3432 $\mathrm{cm}^{-1}$ indicates the presence of intermolecular hydrogen bonding with hydroxyl group with polymeric association. The peak formed at $2777 \mathrm{~cm}^{-1}, 2676 \mathrm{~cm}^{-1}$ is because of C-H stretching and symmetric stretching of methoxy groups present. A small peak at $2071 \mathrm{~cm}^{-1}$ is an attribute to S-H stretching vibration mode. The stretch between 2155 $\mathrm{cm}^{-1}-2161 \mathrm{~cm}^{-1}$ typically formed by triple $\mathrm{C} \equiv \mathrm{C}$ bond in alkynes or because of cumulative double bond in ketones. A minute peak with less intensity at $1069 \mathrm{~cm}^{-1}$ indicates the presence of asymmetric $\mathrm{CH}_{3}$ bending modes of the methyl groups of proteins. The absorption peak formed at $1069 \mathrm{~cm}^{-1}$ is due stretching $\mathrm{C}-\mathrm{N}$, deformation N-H and deformation of $\mathrm{C}-\mathrm{H}$. Peak at $1121 \mathrm{~cm}^{-1}$ and 1069 $\mathrm{cm}^{-1}$ is responsible for polysaccharides and $\mathrm{C}-\mathrm{O}$ stretch associated with glycogen respectively (Fig. 9).

From the spectroscopic studies, Ulva lactuca was preceded for HR-TEM, XRD and seed germination studies. HR-TEM image of Ulva lactuca (Fig. 8)
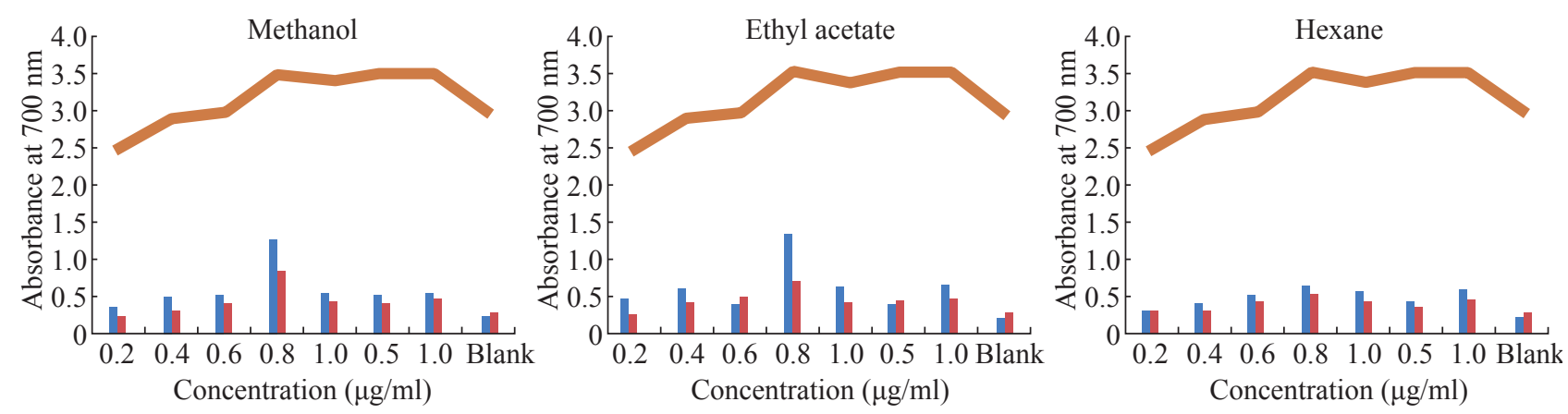

- Ulva lactuca - Caulerpa racemosa - Standard

Fig. 6 Total reducing power assay.
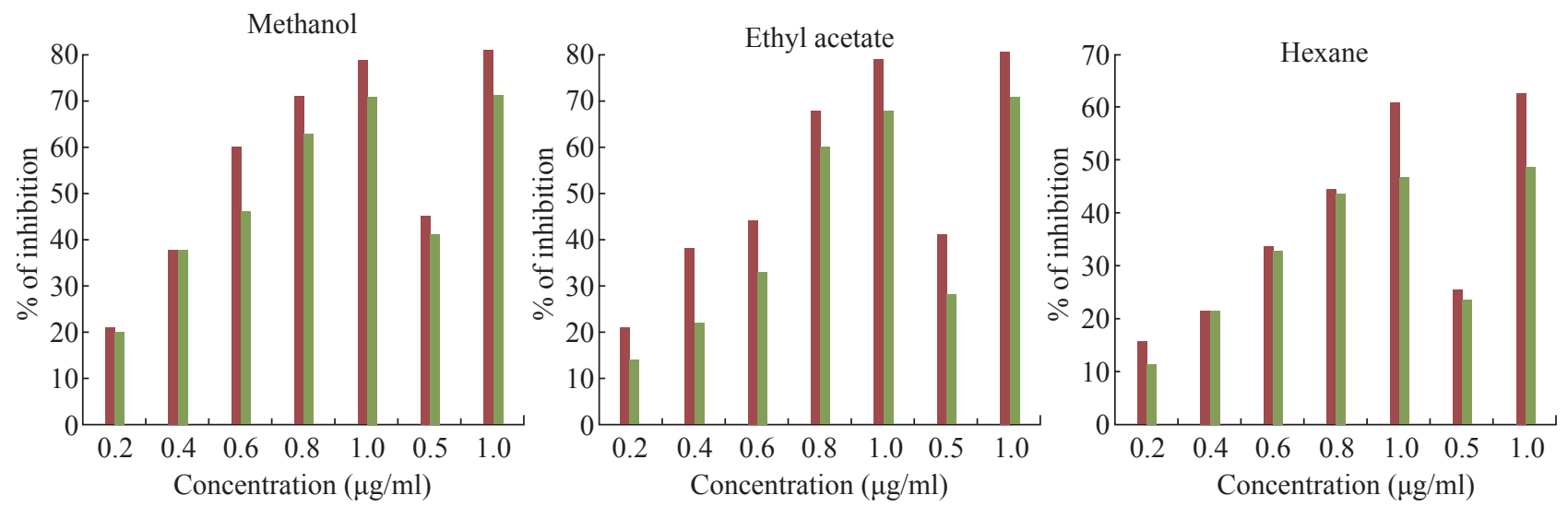

- Ulva lactuca - Caulerpa racemosa

Fig. $7 \mathrm{H}_{2} \mathrm{O}_{2}$ radical scavenging activity. 

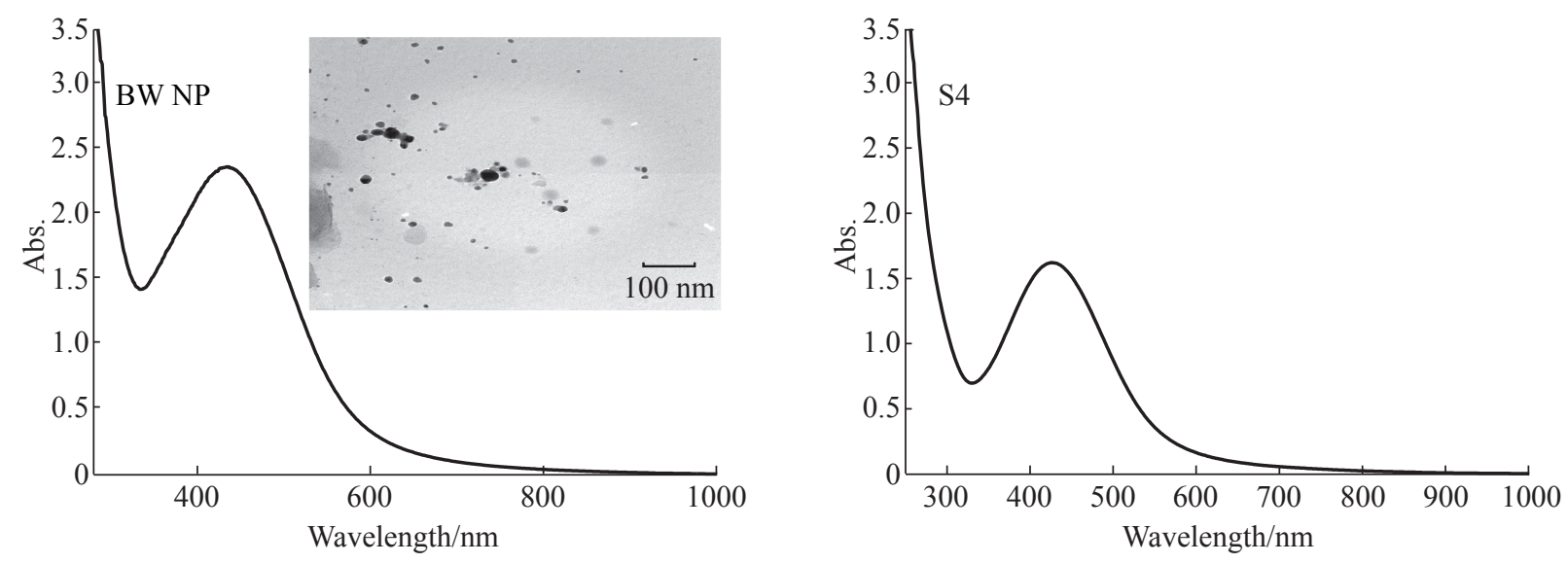

Fig. 8 UV-Visible spectral images of Ulva lactuca with inlet showing HR-TEM image and Caulerpa racemosa (S4).
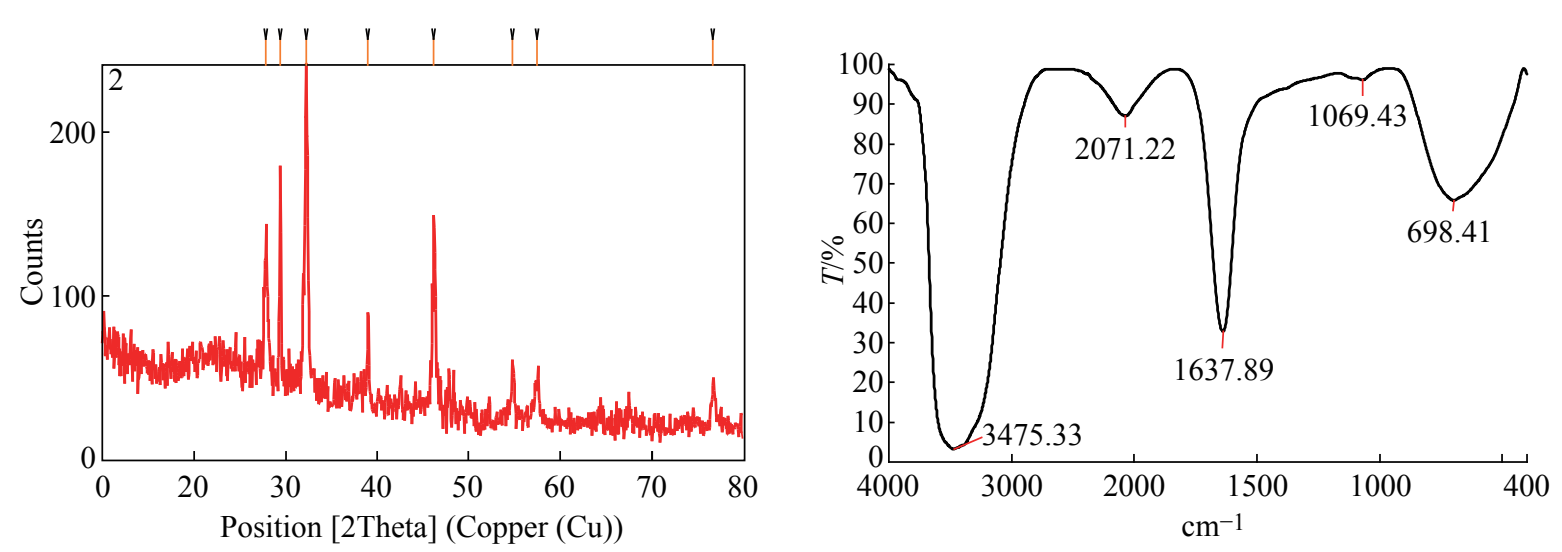

Fig. 9 XRD and FT-IR spectral images of Ulva lactuca synthesized nanoparticles.

shows similar spherical shape and dispersed. From the microscopical analyses and particle size analyzer data, particle size ranging from $35 \mathrm{~nm}-75 \mathrm{~nm}$ was shown in Ulva lactuca. To analyze the structure and composition of the nanoparticles synthesized using seaweeds, X-ray diffraction analysis was performed with $\mathrm{Cu} \mathrm{K} \alpha$ radiation in a $\theta-2 \theta$ configuration. This data confirmed that metallic silver nanoparticles of size 2-5 $\mathrm{nm}$ were being formed. The crystallite domain size was calculated from the width of the XRD peaks, assuming that they are free from non-uniform strains, using the Scherrer's formula (Fig. 9). Extracellular synthesis of nanoparticles could be highly advantageous from the point of view of synthesis in large quantities and easier downstream processing as compared to the intracellular synthesis.

\section{Antibacterial activity of the extract and synthesized particles}

Considering the reflux extracts, maximum zone of inhibition was obtained in Caulerpa racemosa (11 $\mathrm{mm}$ ) against Pseudomonas aeruginosa and minimum of $7 \mathrm{~mm}$ against Staphylococcus aureus at $1 \mathrm{mg} / \mathrm{ml}$ concentration. Whereas, Ulva lactuca at $1 \mathrm{mg} / \mathrm{ml}$ concentration against all the four pathogens showed least maximum zone of inhibition of only $9 \mathrm{~mm}$ diameter.

Comparatively, while assaying the synthesized particles of both samples, maximum zone of inhibition of $18 \mathrm{~mm}$ was shown by Ulva lactuca against Staphylococcus aureus at $1 \mathrm{mg} / \mathrm{ml}$ concentration, whereas Caulerpa racemosa against Pseudomonas aeruginosa $(12 \mathrm{~mm}$ at $1 \mathrm{mg} / \mathrm{ml})$, Escherichia coli and Vibrio cholera $(11 \mathrm{~mm}$ at $1 \mathrm{mg} / \mathrm{ml})$ and no activity even at $1 \mathrm{mg} / \mathrm{ml}$ concentration against Staphylococcus aureus. From the results, Ulva lactuca was highly active to all the tested microorganisms. The production of antimicrobial activities was considered to be an effective indicator of the capability of the seaweeds to synthesize bioactive secondary metabolites (Table 3 ).

\section{Seed germination test}

Seed germination test was done for determination of phytotoxicity of nanoparticles synthesized using 
Table 3 Antibacterial activity of seaweed extracts and synthesized nanoparticles

\begin{tabular}{|c|c|c|c|c|c|c|c|c|c|}
\hline \multirow{2}{*}{ Sample } & \multirow{2}{*}{$\begin{array}{l}\text { Concentration } \\
\quad(\mu \mathrm{g} / \mathrm{ml})\end{array}$} & \multicolumn{4}{|c|}{$\begin{array}{l}\text { Antibacterial activity of seaweed reflux extract } \\
\text { (well diffusion method) in mm }\end{array}$} & \multicolumn{4}{|c|}{$\begin{array}{l}\text { Antibacterial activity of synthesized nanoparticles } \\
\text { (well diffusion method) in mm }\end{array}$} \\
\hline & & $\begin{array}{l}\text { Escherichia } \\
\quad \text { coli }\end{array}$ & $\begin{array}{l}\text { Pseudomonas } \\
\text { aeruginosa }\end{array}$ & $\begin{array}{l}\text { Vibrio } \\
\text { cholerae }\end{array}$ & $\begin{array}{l}\text { Staphylococcus } \\
\text { aureus }\end{array}$ & $\begin{array}{l}\text { Escherichia } \\
\quad \text { coli }\end{array}$ & $\begin{array}{l}\text { Pseudomonas } \\
\text { aeruginosa }\end{array}$ & $\begin{array}{l}\text { Vibrio } \\
\text { cholerae }\end{array}$ & $\begin{array}{l}\text { Staphylococcus } \\
\text { aureus }\end{array}$ \\
\hline \multirow{4}{*}{$\begin{array}{l}\text { Ulva } \\
\text { lactuca }\end{array}$} & 250 & 7 & 6 & - & - & 10 & 11 & 10 & 16 \\
\hline & 500 & 8 & 7 & - & - & 10 & 11 & 10 & 16 \\
\hline & 750 & 9 & 8 & 8 & - & 11 & 12 & 11 & 17 \\
\hline & 1000 & 9 & 9 & 9 & 9 & 11 & 13 & 13 & 18 \\
\hline \multirow{4}{*}{$\begin{array}{l}\text { Caulerpa } \\
\text { racemosa }\end{array}$} & 250 & - & 9 & 7 & - & 9 & 10 & 9 & - \\
\hline & 500 & - & 10 & 8 & - & 10 & 11 & 10 & - \\
\hline & 750 & 8 & 10 & 8 & - & 10 & 11 & 10 & - \\
\hline & 1000 & 9 & 11 & 9 & 7 & 11 & 12 & 11 & - \\
\hline
\end{tabular}

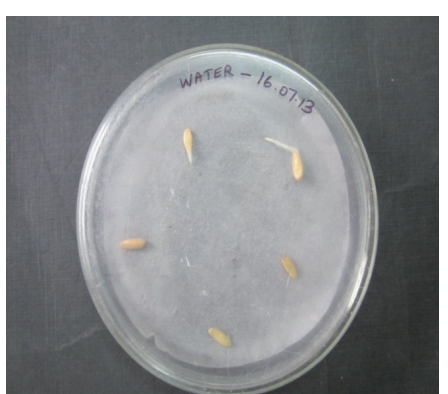

Water extract

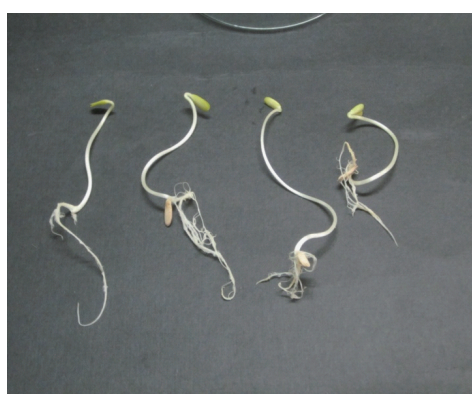

Reflux extract

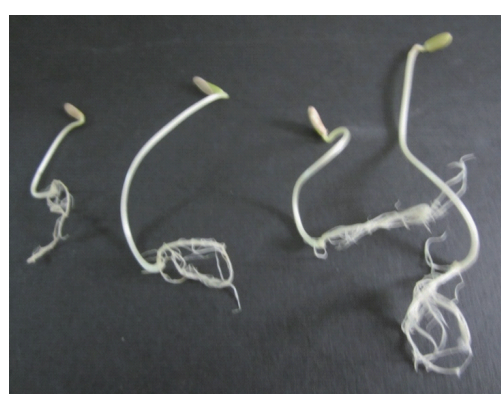

Seaweed nanoparticles

Fig. 10 Morphological changes of cucumber seeds sprayed with water, reflux extract and seaweed nanoparticles by seed germination test.

seaweed extracts by measuring the relative root elongation, germination index and relative seed germination of the seeds for various concentrations after 7 days of incubation. The concentrations ranging from $0.5 \mu \mathrm{g} / \mathrm{ml}$ to $5 \mu \mathrm{g} / \mathrm{ml}$ concentrations was tested, from which $5 \mu \mathrm{g} / \mathrm{ml}$ concentration showed maximum growth in seaweed reflux extract, water and nanoparticle synthesized. Maximum length of both root and shoot was obtained on $5 \mu \mathrm{g} / \mathrm{ml}$ concentration of Ulva lactuca synthesized nanoparticles, whereas minimum growth was seen on reflux extracts of the sample. Root and shoot growth was very least in water (Fig. 10).

From the formula stated in materials and methods, germination index, root elongation and shoot length were calculated accordingly by standard deviation and results were tabulated. These calculated results show that Ulva lactuca nanoparticles have shown maximum growth and germination index at $5 \mu \mathrm{g} / \mathrm{ml}$ concentration.

\section{Conclusion}

The green approach to synthesis of nanoparticles using plant materials, such as reducing and capping agents, could be considered attractive in nanobiotechnology. In recent years, studies on the improvement of biological techniques for synthesis of nanoparticles have been extensively increased due to the harmful effects of chemical preparation methods, in this present work, a nontoxic, green and ecofriendly protocol for the synthesis of silver nanoparticles using seaweeds has been adopted.

The remarkable difference between our results and the results obtained in previous studies may be due to several factors. The main reason can be due to the difference in the seasonal variation of the seaweeds which has been well established from our results. Another important reason can be due to difference in the extraction procedure to recover the active metabolites and differences in assay methods that 
would result in different susceptibilities of the target strains. The prevalence of antimicrobial activities observed in the extracts from the southwest coast of India provides credible evidence that seaweeds maintain effective antimicrobial chemical defenses. From the present study, it can be concluded that the macroalgae are potential sources of bioactive compounds. Further studies are necessary to identify the anticancer activity and catalytic degradation of the synthesized particles.

\section{References}

[1] B. Ankamwar, C. Damle, A. Ahmad and M. Sastry, Biosynthesis of gold and silver nanoparticles using Emblica Officinalis fruit extract, their phase transfer and transmetallation in an organic solution. J Nanosci Nanotech 2005, 5(10): 1665-1671.

[2] V. Armendariz, I. Herrera, J. R. Peralta-Videa, M. JoseYacaman, H. Troiani, P. Santiago and J. L. GardeaTorresdey, Size controlled gold nanoparticle formation by Avena sativa biomass: use of plants in nanobiotechnology. J Nanopart Res 2004, 6(4): 377-382.

[3] R. F. Beers Jr. and I. W. Siezer, A spectrophotometric method for measuring the breakdown of hydrogen peroxide by catalase. J Biol Chem 1952, 195(1): 133-140.

[4] A. Bennett and L. Bogorad, Comparative chromatic adaptation in a filamentous blue-green alga. $\mathrm{J}$ Cell Biol 1973, 58(2): 419-435.

[5] M. M. Bradford, A rapid and sensitive method for the quantitation of microgram quantities of protein utilizing the principle of protein-dye binding. Analytical Biochemistry 1976, 72(7): 248-254.

[6] S. Broesch, Colorimetric assay of phenol oxidase. Bull Sac Chem Bio 1954, 36: 711-713.

[7] G. X. Chen and K. Asada, Ascorbate peroxidase in tea leaves: Occurrence of two isozymes and the differences in their enzymatic and molecular properties. Plant Cell Physiol 1989, 30(7): 987-998.

[8] M. Dubois, K. A. Gilles, J. K. Hamilton, P. A. Rebers and F. Smith, Calorimetric method for determination of sugars and related substances. Anal Chem 1956, 28(3): 350-356.

[9] F. Gao, Q. Lu, and S. Komarneni, Interface reaction for the self-assembly of silver nanocrystals under microwaveassisted solvothermal conditions. Chem Mater 2005, 17(4): 856-860.

[10] F. Jordi, M. Lees and S. G. H. Stanley, A simple method for the isolation and purification of total lipids from animal tissues. Journal of Biological Chemistry 1956, 226(1): 497-509.

[11] J. L. Gardea-Torresdey, J. G. Parsons, E. Gomez, J. Peralta-Videa, H. E. Troiani, P. Santiago and M. J. Yacaman, Formation and growth of Au nanoparticles inside live Alfalfa plants. Nano Lett 2002, 2(4): 397-401.

[12] J. L. Gardea-Torresdey, E. Gomez, J. R. Peralta-Videa, J. G. Parsons, H. Troiani and M. J. Yacaman, A natural source for the synthesis of silver nanoparticles. Langmuir 2003, 19(4): 1357-1361.

[13] H. H. Abd El-Baky, F. K. El Baz and G. S.E Baroty, Evaluation of marine algae Ulva lactuca. L as a source of Natural Preservative Ingredient. American-Eurasian $J$ Agric \& Environ Sci 2008, 3(3): 434-444.

[14] Y. L. Hou, H. Kondoh, T. Kogure, and T. Ohta, Preparation and characterization of monodisperse $\mathrm{FePd}$ nanoparticles. Chem Mater 2004, 16(24): 5149-5152.

[15] A. Ingle, A. Gade, S. Pierrat, C. Sonnichsen and M. Rai, Mycosynthesis of silver nanoparticles using the fungus Fusarium acuminatum and its activity against some human pathogenic bacteria. Curr Nano 2008, 4(2): 141144.

[16] R. Julkunen-Tiitto, Phenolics constituents in the leaves of northern willows: Methods for the analysis of certain phenolics. J Agr Food Chem 1985, 33(2): 213-217.

[17] H. Kikuzaki, and N. Nakatani, An effect of some ginger constituents. J Food Science 1993, 58(6): 1407-1410.

[18] K. B. Kumar and P. A. Khan, Peroxidase and polyphenol oxidase in excised ragi (Eleusine coracana cv. PR 202) leaves during senescence. Ind J Exp Bot 1982, 20: 412416.

[19] P. Kumar, S. Senthamil Selvi, A. Lakshmi Prabha, K. Prem Kumar, R. S. Ganeshkumar and M. Govindaraju, Synthesis of silver nanoparticles from Sargassum tenerrimum and screening phytochemicals for its antibacterial activity. Nano Biomed Eng 2012, 4(1): 1216.

[20] L. D. Keun and Y. S. Kang, Synthesis of silver nanocrystallites by a new thermal decomposition method and their characterization. ETRI Journal 2004, 26(3): 252-256.

[21] H. P. Liang, Y. G. Guo, H. M. Zhang, J. S. Hu, L. J. Wan and C. L. Bai, Controllable AuPt bimetallic hollow nanostructures. Chem Commun 2004, 13: 1496-1497.

[22] P. Mansuya, P. Aruna, S. Sridhar, J. S. Kumar and S. Babu, Antibacterial activity and qualitative phytochemical analysis of selected seaweeds from gulf of mannar region. J Exp Sci 2010, 1(8): 23-26.

[23] C. McKinney, Absorption of light by chlorophyll solutions. J Biol Chem 1941, 140: 315-332.

[24] M. Forough and K. Farhadi, Biological and green synthesis of silver nanoparticles. Turkish J Eng Env Sci 2010, 34: 281-287.

[25] V. I. Perekrestov, Single crystal aluminum deposit formation on isotropic substrates by means of selforganized ion sputtering. Tech Phys Lett 2006, 31(10): 868-870.

[26] P. Prieto, M. Pineda and M. Aguilar, Spectrophotometric quantitation of antioxidant capacity through the formation of a phosphomolybdenum complex: specific application to the determination of Vitamin E. Analytical Biochemistry 1999, 269(2): 337-341.

[27] P. Raveendran, J. Fu and S. L. Wallen, Completely "green" synthesis and stabilization of metal nanoparticles. $J \mathrm{Am}$ Chem Soc 2003, 125(46): 13940-13941.

[28] R. Barrena, E. Casals, J. Colon, X. Font, A. Sanchez and V. Puntes, Evaluation of the ecotoxicity of model nanoparticles. Chemosphere 2009, 75(7): 850-857.

[29] J. A. Reinheimer, M. R. Demkow and M. C. Condioti, Inhibition of coliform bacteria by lactic cultures. Austr $J$ Dairy Technol 1990, 45(1): 5-9.

[30] S. S. Shankar, A. Ahmad and M. Sastry, Geranium leaf assisted biosynthesis of silver nanoparticles. Biotechnol Prog 2003, 19(6): 1627-1631.

[31] S. S. Shankar, A. Rai, A. Ahmad and M. Sastry, Rapid synthesis of $\mathrm{Au}, \mathrm{Ag}$, and bimetallic Au core-Ag shell nanoparticles using Neem (Azadirachta indica) leaf broth. J Colloid Interface Sci 2004, 275(2): 496-502.

[32] S. Shukla, A. Priscilla, M. Banerjee, R. R. Bhonde, J. Ghatak, P. V. Satyam and M. Sastry, Porous gold nanospheres by controlled transmetallation reaction: a novel material for application in cell imaging. Chem Mater 2005, 17: 5000-5005.

[33] G. Singaravelu, J. Arockiyamari, V. Ganesh Kumar and K. Govindaraju, A novel extracellular biosynthesis of monodisperse gold nanoparticles using marine algae, 
Sargassum wightii Greville. Colloids and Surfaces B: Biointerfaces 2007, 57(1): 97-100.

[34] M. S. Taga, E. E. Miller, D. E. and Pratt, Chia seeds as a source of natural lipids antioxidants. $J$ Am Oil Chem Soc 1984, 61(5): 928-993.

[35] K. N. Thakkar, S. S. Mhatre and R. Y. Parikh, Biological synthesis of metallic nanoparticles. Nanomedicine 2010, 6(2): 257-262.

[36] S. M. Tiquia, N. F. Y. Tam and I. J. Hodgkiss, Effects of composting on phytotoxicity of spent pig-manure sawdust litter. Environ Pollut 1996, 93(3): 249-256.

[37] S. M. Tiquia and N. F. Y. Tam, Elimination of phytotoxicity during co-composting of spent pig-manure sawdust litter and pig sludge. Bioresource Technology 1998, 65(1): 43-49.

Copyright $\odot 2014$ Dhanalakshmi Aravindan, Riyazulla Azeez and Thangaraju Nallamuthu. This is an open-access article distributed under the terms of the Creative Commons Attribution License, which permits unrestricted use, distribution, and reproduction in any medium, provided the original author and source are credited. 